\title{
ANALYSIS OF FUEL CONSUMPTION SENSITIVITY IN FORESTRY ROAD TRANSPORT
}

\author{
Pompeu Paes Guimarães ${ }^{1 *}$, Julio Eduardo Arce ${ }^{2}$, Eduardo da Silva Lopes ${ }^{3}$, Nilton Cesar Fiedler ${ }^{4}$, Renato César \\ Gonçalves Robert ${ }^{5}$, Fernando Seixas ${ }^{6}$
$1^{*}$ Federal Rural University of the Semi-Arid, Center for Agrarian Sciences, Department of Forestry and Agronomic Sciences, Mossoró, Rio Grande do Norte, Brazil - pompeu.guimaraes@ufersa.edu.br
${ }^{2}$ Federal University of Paraná, Department of Forestry Sciences, Curitiba, Paraná, Brazil - jarce@ufpr.br
${ }^{3}$ State University of the Midwest, Department of Forest Engineering, Irati, Paraná, Brazil - eslopes@ unicentro.br
${ }^{4}$ Federal University of Espírito Santo, Department of Forest Engineering, Jerônimo Monteiro, Espírito Santo, Brazil - fiedler@pq.cnpq.br
${ }^{5}$ Federal University of Paraná, Department of Forest Engineering and Technology, Curitiba, Paraná, Brazil - renatorobert@ufpr.br \\ ${ }^{6}$ Luiz de Queiroz College of Agriculture, Department of Forestry Sciences, Piracicaba, São Paulo - fseixas @ usp.br
}

Received for publication: 03/11/2016 - Accepted for publication: 20/08/2018

\begin{abstract}
The objective of this work was to analyze how the variation of traveled distance, operational speed, journey time and net cargo transported influence the fuel consumption of vehicles in forest road transport. The data were collected in this operation, covering the area between the regions of Campo do Tenente (forest unit) and Piên (industrial unit), in the state of Paraná. We analyzed the partial elements, loaded trip and empty trip, as well as the total transport cycle (loading, unloading and travel). Using the same mechanical tractor, two vehicular compositions were studied, an articulated vehicle (truck tractor + semitrailer + trailer) and a conjugated vehicle (truck tractor + semitrailer). The vehicle telemetric system was used to perform the data collection of travel time, traveled distance, speed average and fuel consumption of the both vehicles. The results showed that the higher fuel consumption occurred in the loaded trips for longer distances. The sensitivity of fuel consumption was mostly influenced by was traveled distance, so it is recommended the use of vehicles of less load capacity for shorter distances.

Keywords: Logistics, planning and forestry supply.
\end{abstract}

\begin{abstract}
Resumo
Análise de sensibilidade do consumo de combustível no transporte rodoviário florestal. Este trabalho teve como objetivo analisar como a variação de distância percorrida, velocidade operacional, duração da viagem e carga líquida transportada influenciam no consumo de combustível de veículos no transporte rodoviário florestal. Os dados foram coletados nesta operação, contemplando o trecho localizado entre as regiões de Campo do Tenente (unidade florestal) e Piên (unidade industrial), estado do Paraná. Foram analisados os elementos parciais viagem carregado e viagem vazio, bem como o ciclo total de transporte (carregamento, descarregamento e viagens). Foram estudadas composições veiculares de carga com o mesmo cavalo mecânico, sendo um conjugado (cavalo mecânico + semirreboque + reboque) e um articulado (cavalo mecânico + semirreboque). $\mathrm{O}$ sistema de telemetria do veículo possibilitou a realização da coleta de dados relativos à duração, distância percorrida, velocidade média e consumo de combustível de ambos os veículos. Os resultados mostraram que o maior consumo de combustível ocorreu no elemento viagem carregado, nas maiores distâncias de transporte. A variável que mais influenciou na sensibilidade do consumo de combustível dos veículos foi a distância percorrida, sendo recomendado o uso de veículos com menor capacidade de carga nas menores distâncias de transporte.

Palavras-chave: Logística, planejamento e abastecimento florestal.
\end{abstract}

\section{Introduction}

Harvesting and transporting of wood are generally the costliest operations in the forest production chain. Transportation is impacted by the impossibility of using vehicles with higher load capacity due to the poor quality of roads, especially in terms of slopes and steep declivity and pavement quality standards (FIEDLER, 2018).

The road modal has been privileged in public policy decisions, probably due to the absence of long-term cost analysis (ELLER et al., 2011). In relation to Brazilian log transport, shipment costs account for up to $60 \%$ of the total logistics cost (ALVES et al., 2013).

In this process a large volume of wood is moved through rural and urban (paved) roads (ANTONIADE et al., 2012). In the case of log handling, the characteristics of load specificity and shipment exclusivity allow the vehicle to operate loaded in only one direction, causing costs to become larger per unit volume (MACHADO et al., 2009). The empty route does not directly contribute to the company's profit, but is essential for the continuity of operations and maintenance of the level of service. The distribution of vehicles to balance supply and demand

FLORESTA, Curitiba, PR, v. 49, n. 2, p. 155-162, abr/jun 2019.

Guimarães. P. P. et.al.

ISSN eletrônico 1982-4688

DOI: $10.5380 /$ rf.v49 i 2.49137 
in future periods is a central component of planning and one of the major challenges for fleet management (VASCO and MORABICO, 2014).

The companies providing forest road transport services have high costs with machines and direct implements, a small number of employees, however, with high salaries, and still present smaller proportions of fixed costs in relation to the variables (QUADROS and MALINOVSKI, 2012).

For Silva et al. (2007), forest supply management studies should be conducted to identify the type of vehicle best suited for transporting timber from a particular region or enterprise. Another problem is related to the maximum feasible distance traveled, since the high cost has great power to make an entire reforestation project unviable with the extension of the consumer center.

A constant doubt in the planning of the forest transport consists of the choice of the best vehicular composition of load, selection of the mechanical horse related to the engine, tractive maximum capacity and volume of the fuel tank (BENETTI et al., 2018).

Two of the configurations commonly used in Brazilian forest road transportation are the wagon and the road train. The first, or articulated vehicle, has two units, a tractor (mechanical horse) and a semi-trailer, a unit with one or more rear axles. When coupling one more unit, a trailer, which moves traction, this vehicle receives the denomination of road train (road train) (MACHADO et al., 2009; GUIMARAES et al., 2016a).

In addition to the concern with the fleet, road quality interferes with user safety, speed and operational cost. The reason for this observation is the high density of roads observed in reforestation areas, encumber the management of these roads (CARMO et al., 2013, EMMERT et al., 2010).

Based on the assumption that the difference between the load composition of the road train and for the wagon is the insertion of one more unit (trailer), the increase in the distance traveled, the operational speed, duration and quantity of logs transported per transport cycle cause changes in consumption of vehicles.

The objective of this work was to analyze the fuel consumption in function of the variation of the variables - distance traveled, average speed, duration and liquid load carried - of two vehicle load compositions.

\section{MATERIAL AND METHODS}

Data were collected on the operational system of forest road transport to an industrial unit located in the municipality of Piên, Paraná, with forest stands located in Campo do Tenente. The species transported was Pinus taeda L. (Pinaceae), in the format of logs, for consumption as a process by the industry (18 to $25 \mathrm{~cm}$ in diameter), having been planted 1,600 trees in one hectare and harvested at 15 years in the regime with an average increment of $40 \mathrm{~m}^{3}$ per hectare per year.

The short-log harvesting system (cut-to-length) was used, with the use of harvester for logging and forwarder for log extraction ( $2.6 \mathrm{~m}$ long). The harvesting system was cold, with the logs stacked for up to three months at the roadside.

For the loading of the wood in field, a forestry loader composed of a hydraulic excavator base machine was used with Caterpillar brand CAT 312D L, 3054C engine, rated power of 90.0 HP, equipped with a brand gripper Timber Forest, with a floor area of $0.8 \mathrm{~m}^{2}$ and an average range of $9.0 \mathrm{~m}$.

The wooden unloader in the industrial unit consisted of a hydraulic excavator base machine with treadmills of the brand Volvo, model EC210, rated power of 143 HP, equipped with claw of mark J of Souza, with floor area of $1.35 \mathrm{~m}^{2}$ and average range of $10.8 \mathrm{~m}$. (Table 1).

The forest road transport comprised the phases of loading, loaded trip, unloading and empty journey

Table 1. Phases of forest road haulage.

Tabela 1. Etapas do transporte rodoviário florestal.

\begin{tabular}{|c|c|c|c|}
\hline 1 Loading & 2 Trip loaded & 3 Offloading & 4 Empty travel \\
\hline $\begin{array}{l}\text { 1.1 The vehicle arrived at the } \\
\text { guardhouse of the forest unit in } \\
\text { Campo do Tenente (PR); } \\
\text { 1.2 It moved to the region where the } \\
\text { loading would take place; } \\
\text { 1.3 Proper loading of logs by the } \\
\text { forestry loader into the vehicle's cargo } \\
\text { compartment; } \\
\text { 1.4 Connecting the belts to hold the } \\
\text { load; } \\
\text { 1.5 Displacement to the forestry unit's } \\
\text { guardhouse for manual measurement } \\
\text { of cargo and invoice issuance. }\end{array}$ & $\begin{array}{l}\text { 2.1 Displacement of } \\
\text { vehicles from the } \\
\text { route of the } \\
\text { guardhouse of the } \\
\text { forest unit to the } \\
\text { guardhouse of the } \\
\text { industrial unit. }\end{array}$ & $\begin{array}{l}\text { 3.1 Pre-registration and weighing } \\
\text { steps; } \\
\text { 3.2 Driving to the unloading } \\
\text { region; } \\
\text { 3.3 Properly unloading of logs } \\
\text { from the vehicle's cargo } \\
\text { compartment and depositing in } \\
\text { the piles in the yard; } \\
\text { 3.4 Cleaning the vehicle's } \\
\text { combination: } \\
\text { 3.5 Displacement back to the } \\
\text { concierge and empty vehicle } \\
\text { weighing. }\end{array}$ & $\begin{array}{l}\text { 4.1 Displacement } \\
\text { of vehicles from } \\
\text { the route of the } \\
\text { guardhouse of the } \\
\text { industrial unit to } \\
\text { the guardhouse of } \\
\text { the forest unit. }\end{array}$ \\
\hline
\end{tabular}


Table 2 shows the specifications of the carrier vehicle compositions used.

Table 2. Specifications of vehicles used.

Tabela 2. Especificações dos veículos utilizados.

\begin{tabular}{|c|c|c|}
\hline 1 Tractor & 2 Conjugated vehicle & 3. Articulated vehicle \\
\hline $\begin{array}{l}\text { 1.1 Driving cab - Low bed; } \\
\text { 1.2 Maximum load on single axle }-6,000 \mathrm{~kg} \text {; } \\
\text { 1.3 Maximum unconjugated load of double } \\
\text { tandem axes }-17,000,0 \mathrm{~kg} \text {; } \\
\text { 1.4 Front balance }-1,440 \mathrm{~mm} \text {; } \\
\text { 1.5 Minimum distance from the center of the axle } \\
\text { to the body }-900.0 \mathrm{~mm} \text {; } \\
1.6 \text { Whellbase }-3,300.0 \mathrm{~mm} \text {; } \\
1.7 \text { Chassis weight with cab on the front axle - } \\
4,800.0 \mathrm{~kg} \text {; } \\
1.8 \text { Chassis weight with cab on the rear axle - } \\
3,800.0 \mathrm{~kg} \text {; } \\
1.9 \text { Chassis weight with total cab }-8,700.0 \mathrm{~kg} \text {; } \\
\text { 1.10 Power/weight ratio }-40 / 25 \text {; } \\
1.11 \text { Traction }-6 \mathrm{x} 2 \text {; } \\
\text { 1.12 Brake system }- \text { Pneumatic disc. }\end{array}$ & $\begin{array}{l}\text { 2.1 Train Road - Composition: } \\
\text { Tractor + semi-trailer + trailer; } \\
2.2 \text { Maximum load on the triple } \\
\text { tandem axes assembly of the semi- } \\
\text { trailer }-25,500,0 \mathrm{~kg} \text {; } \\
\text { 2.3 Maximum load on the rear and } \\
\text { front double axis }-20,000.0 \mathrm{~kg} \text {; } \\
2.4 \text { PBTC }-68,500.0 \mathrm{~kg} ; \\
2.5 \text { PBTC }+5 \%-72,000.0 \mathrm{~kg} ; \\
2.6 \text { Collection period }-10 / 17 / 2012 \\
\text { to } 11 / 07 / 2012 \text {; } \\
\text { 2.7 Operating cycles collected - } \\
\text { 22.0. }\end{array}$ & $\begin{array}{l}\text { 3.1 Wagon - Composition: } \\
\text { Tractor + semi-trailer; } \\
\text { 3.2 Maximum load on the } \\
\text { triple tandem axes assembly } \\
\text { of the semi-trailer }-25,500,0 \\
\mathrm{~kg} \text {; } \\
3.3 \text { PBTC }-48,500.0 \mathrm{~kg} \text {; } \\
3.4 \text { PBTC }+5 \%-51,000.0 \\
\mathrm{~kg} ; \\
3.5 \text { Collection period }- \\
11 / 07 / 2012 \text { to } 02 / 22 / 2013 \text {; } \\
\text { 3.6 Operational Cycles } \\
\text { Collected - } 107.0 \text {. }\end{array}$ \\
\hline
\end{tabular}

It should be noted that the routes used by the drivers when loaded traveling were different from the routes in transit with empty vehicles, a fact that is justified by the need to get around inhabited areas and with greater traffic. The route traced for the loaded trip was $89.3 \mathrm{~km}$, with a total of $3 \%$ of asphalted roads. The return route was equivalent to $44.1 \mathrm{~km}$, with $7.7 \%$ of asphalt.

From the travel period stored by the telemetry system, the Duration (D) of each cycle activity was collected in minutes; Distance traveled (Q), in kilometers; Operating speed (V) developed by the vehicle during the transport cycle, in kilometers per hour; and Fuel consumption (C) of each vehicle during the operational cycle, in liters.

With the records of the departure and arrival times of the vehicles of the guardhouse of the forest and industrial unit, the times related to the internal displacement and loading, loaded trip, unloading, empty trip and total cycle were filtered. The net load carried per cycle was obtained by the difference between the weight of the vehicle loaded and empty.

To perform the sensitivity analysis of the dependent variable fuel consumption, it was necessary to define an equation (Stepwise) whose result was dependent on the values assumed by the independent variables (Table 3).

Table 3. Equations adjusted for forest road haulage.

Tabela 3. Equações ajustadas para o transporte rodoviário florestal.

\begin{tabular}{|c|c|c|}
\hline Total Cycle & Equation* & \\
\hline Conjugated vehicle & $C=4,00 \cdot 10^{2}+6,82 \cdot 10^{-3} Q^{2}-3,22 \cdot 10^{-5} Q M-9,62 \cdot 10^{-5} M^{-1}$ & $R_{a j(\%)}^{2}=81,0 \quad S_{y x(\%)}=6,7$ \\
\hline Articulated vehicle & $\ln C=3,83-20,27 D^{-1}+4,92 \cdot 10^{-3} Q+0,83 V^{-1}+1,01 \cdot 10^{-10} M^{2}$ & $R_{a j(\%)}^{2}=91,5 S_{y x(\%)}=4,8$ \\
\hline
\end{tabular}

The sensitivity analysis was performed by modifying the main components of forest road transport fuel consumption by $\pm 10 \%$, as methodology applied by Silva et al . (2007).

The independent variables (duration, distance traveled, operating speed and liquid load transported) were modified to $\pm 10 \%$ and presented in a three-dimensional graph (surfaces) in relation to the behavior of the fuel consumption (dependent variable), called response surface.

\section{Results}

For the descriptive statistics, 22 cycles were collected with the conjugate and 107 cycles with the articulation (Figure 1). The difference between the number of cycles collected was due to the use of the same mechanical horse, without interference in the employee process for the analyzed company. 


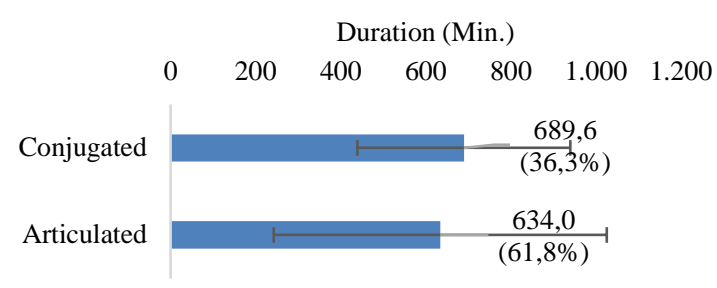

(a)

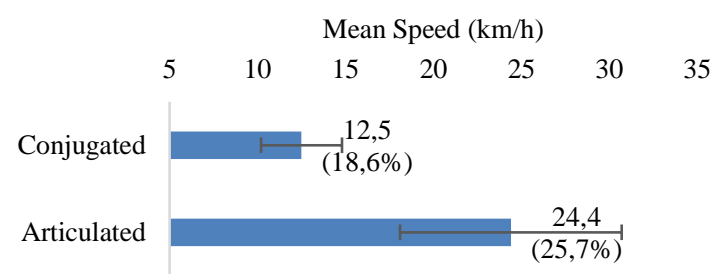

(c)

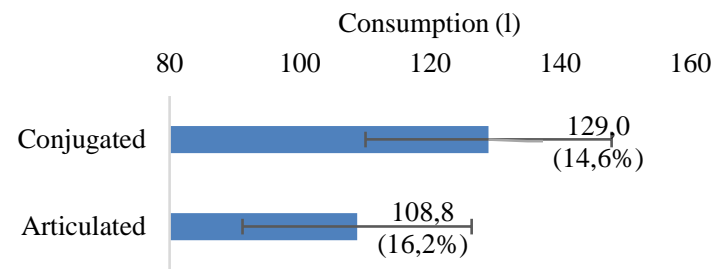

(e)

Figure 1.Descriptive statistics of forest road haulage.

Figura 1. Estatísticas descritivas do transporte rodoviário florestal.

Figure 2 shows the sensitivity analysis for the estimated fuel consumption of vehicles used in forest road transport.

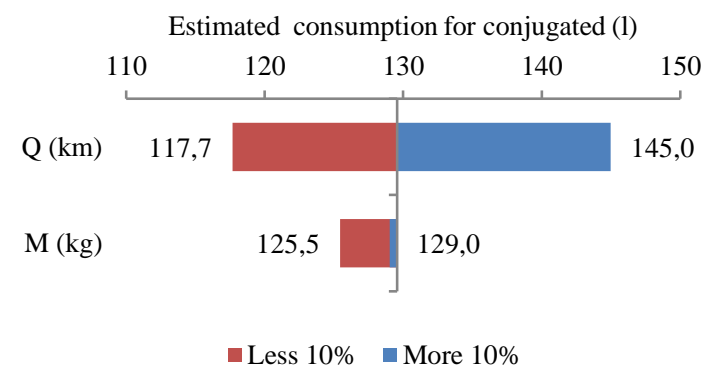

(a)

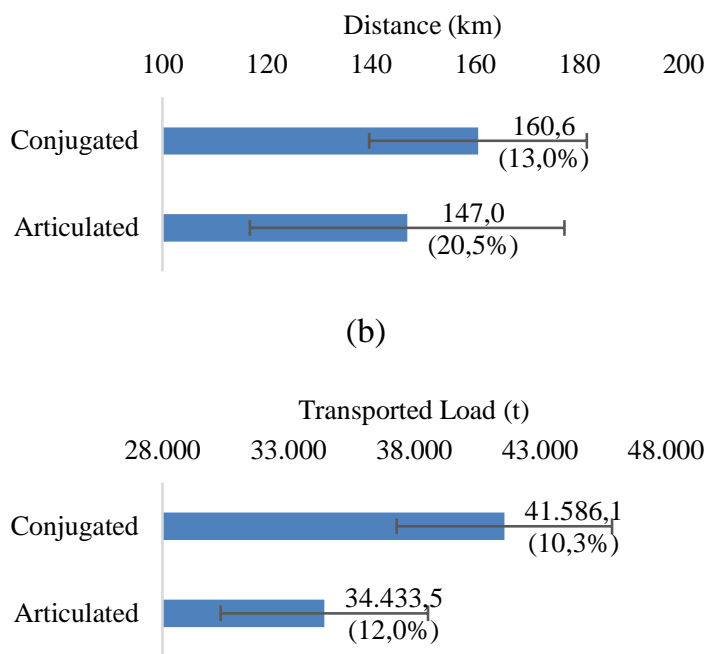

(d) 


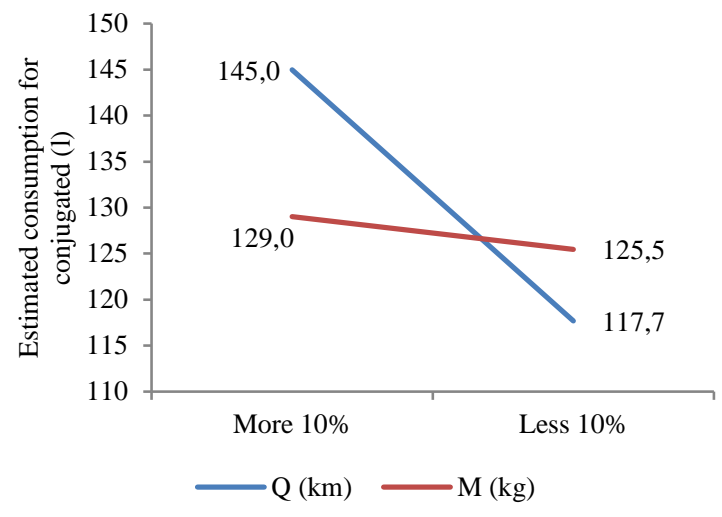

(c)

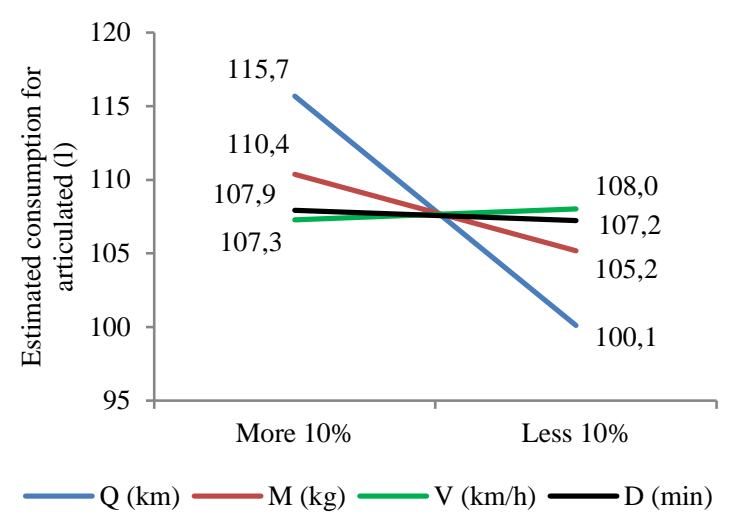

(d)

Figure 2. Sensitivity of estimated fuel consumption of forest haulage vehicles.

Figura 2. Sensibilidade do consumo estimado de combustível dos veículos do transporte florestal

For the construction of the response surface in the total transport cycle with the hinged it was necessary to use the average duration of $634.0 \mathrm{~min}$ and the average speed of $24.4 \mathrm{~km} / \mathrm{h}$.

A mean duration of $634.0 \mathrm{~min}$ and an average speed of $24.4 \mathrm{~km} / \mathrm{h}$ were used to construct the surface in the total transport cycle with the articulation, since these variables had a lower influence on the variation in consumption. transport.

Figure 3 shows the surface of answer for the estimated fuel consumption of vehicles used in forest road

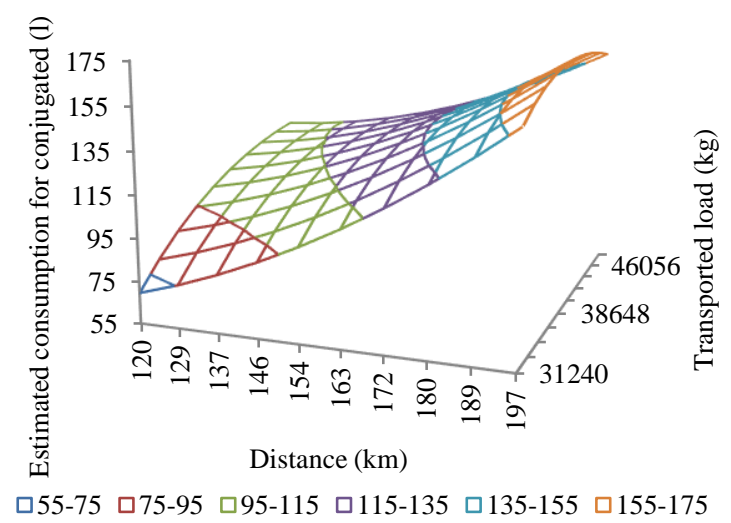

(a)

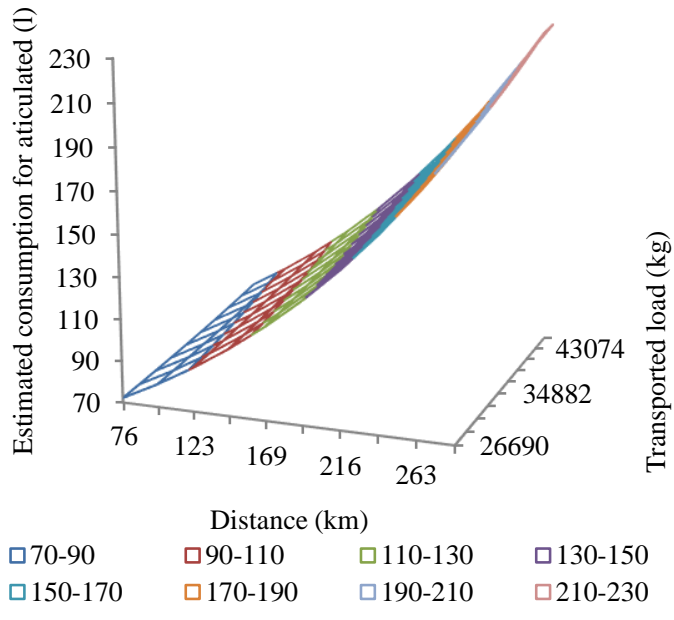

(b)

Figure 3. Response surface for estimated fuel consumption of vehicles.

Figura 3. Superfície de respostas para o consumo estimado de combustível dos veículos.

\section{DISCUSSION}

The conjugated vehicle had the highest load carried per cycle. However, with the articles, it was united the shorter cycle duration; travelled distance; and fuel consumption. As well as the higher operational speed.

The duration of the total cycle was variable, as demonstrated by the high coefficients of variation. During the working day of $1.440 \mathrm{~min}(24 \mathrm{~h})$ each driver took, on average, $689.6 \mathrm{~min}$. to complete each cycle with the conjugate and $634 \mathrm{~min}$. with the articles. In this way, it was possible to complete 2.1 cycles with the conjugate and 2.3 with the articulation. By reducing the cycle time, more trips can be made during the work day, avoiding the loss of time with the vehicles stopped and allowing greater load for the industrial plant. 
The driver was remunerated for completed cycle, that is, for cargo unloaded at the industrial unit. Taking into account the standard deviation of the duration when it is at its lower limit, it was possible to complete a cycle in a shorter time, and with this, respectively for the conjugate and for the articulation, reach 3.3 and 5.9 total cycles.

Each transport cycle using the conjugate covered an average of $160.6 \mathrm{~km}$ and with the articulation 147.0 $\mathrm{km}$. At the beginning of the data collection with the use of the conjugate the loading fronts were $13 \mathrm{~km}$ farther than in the course evaluated with the articulated. On average, the distance traveled on the loaded and empty trip was similar with the use of both vehicles.

In relation to the operating speed, the total cycle with the conjugate presented an average speed of 12.5 $\mathrm{km} / \mathrm{h}$. The articulated vehicle reached double the speed reached by the conjugate.

It should be noted that the total cycle involved, in addition to the loaded and empty journeys, the loading and unloading stages. In these passive phases the driver remained, for a large portion, with the vehicles turned off or in maneuvers. The displacement of the guardhouse of the forest unit to the loading fronts and vice versa were also counted in the loading times. In these places the means of conduction occurred in forest roads that in the great majority are not paved and, therefore, result in lower operational speed.

The tare weight of the combination vehicle and the articles corresponded respectively to $24,922.2 \mathrm{~kg}$ and $21,326.8 \mathrm{~kg}$. The conjugate transported on average $41,586.1 \mathrm{~kg}$, being below the allowed limit of $68,500 \mathrm{~kg}$. When analyzing the load carried with the articulated, it took on average $34,433,5 \mathrm{~kg}$ of logs, occurring overload, being above the allowed $48,500 \mathrm{~kg}$. The conjugate led $17.3 \%$ more wood in relation to the articulation.

The excess load per axle reduces the road service life of the road, the vehicle itself, springs and brakes, causing premature wear and increasing the risk of accidents on the road. It also makes it difficult to climb forest road vehicles up the slope and boost slope speeds. And the main reason for carrying only the allowable amount of wood is the reduction of damage to drivers and other victims. In a study on the profile of drivers of forest road transport, Guimaraes et al. (2013) pointed out that $26 \%$ of those evaluated already suffered accidents, $80 \%$ of these caused by vehicle tipping.

The conjugate had an equivalent energy yield of 49.5 , while the articulation reached 43.9 t.km/l. For the same transport cycle, it was possible to transport $5.6 \mathrm{t}(11.3 \%)$ more wood with the conjugate in relation to the loaded one, for $1 \mathrm{~km}$ and with 11 of fuel. Even so, the energy yield was lower than that presented by Machado et al. (2009). In this way the transport with the conjugate is more advantageous than with the article.

\section{Sensitivity analysis for estimated fuel consumption}

The cycle of forest road transport had average consumption of 129.6 1/cycle for the conjugate, for a mean distance traveled and average liquid load transported.

By varying the distance traveled in paths $10 \%$ lower for the total transport cycle with the conjugate while maintaining the average liquid load carried, there was a reduction of $11.61 /$ transport cycle, while, with a $10 \%$ of the distance there was a higher estimated fuel consumption in the range of $15.41 /$ cycle.

Conducting $10 \%$ less load on the conjugate, there was a reduction in 4.6 l/cycle, adding $10 \%$ of net cargo transported, there was also a lower consumption of $0.61 /$ cycle. This variation was inherent to the adjusted equation. It must be transported with the use of the conjugate $43,500,0$ t to traffic with the maximum amount allowed by the legislation.

The conjugate should be used for the longest journeys (distance covered 10\% higher) and load of 43,500.0 $\mathrm{t}$, resulting in an increase of 14.7 1/cycle to maximize the amount of wood transported.

When the vehicle used was the articulated, all the variables of the operational cycle influenced in the fuel consumption, maintaining its average, were consumed $107.6 \mathrm{l} /$ transport cycle.

In a path $10 \%$ lower distance traveled distance, $7.6 \mathrm{l} / \mathrm{cycle}$ is reduced with the articulated, in the same way that transporting $10 \%$ less of load promoted an estimated consumption lower in 2.6 1/cycle. Following this logic, $10 \%$ less in cycle length with the use of articulated vehicle would reduce by 0.61 . For a reduction of $10 \%$ of the operational speed would require 0.61 of extra fuel to complete the same cycle with the articulation.

The results obtained with the reduction of the operational speed are in agreement with the studies of Seixas and Widmer (1993), who demonstrated the importance of the determination, more accurate, of the values of average speed that represent the approximate way of the performance of the vehicles in the situations of each company.

By bringing the logs at greater distances in the industry and forest route using the articulated, there was an increase of 8.4 1/cycle, just as with an additional liquid load of $10 \%$ greater would require 2.41 of extra fuel per cycle.

The reduction in the wooden amount carried by the articulated one would have to be in the $21 \%$ order to adjust itself to the liquid load allowed by the legislation $(27,286,96 \mathrm{t})$. For the shortest transport distances $(10 \%$ 
lower), with a duration of $10 \%$ less and an operational speed $10 \%$ higher $(26.8 \mathrm{~km} / \mathrm{h})$ there would be a reduction of $12.61 /$ trip.

In order to ensure greater security and maintenance of supply, the forest unit should be located as close as possible to the production area, and when forests are distant from the industry, the alternative found to reduce transport costs is the use of vehicles with greater load and power capacity, such as the conjugate.

For smaller trains, carrying the maximum allowable quantity of wood, reduced loading and unloading times, reduced fuel consumption and reduced cycle time with the articulation. It is concluded that, for smaller distances, vehicles with less load capacity should be used, allowing agility of the passive stages.

\section{Response surface for estimated fuel consumption of vehicles.}

For the total transport cycle with the conjugate, traveling an average distance of $160.0 \mathrm{~km}$, loaded on average of 41,586.1 there was a consumption of 129.21 of fuel.

The maximum load carried by the conjugate should be 43,500,0 t so that it does not exceed $68,500.0 \mathrm{~kg}$ of PBTC. With this load, for the longest distance $(185.0 \mathrm{~km})$, there would be an estimated consumption of 153.11 and an efficiency of $1.21 \mathrm{~km} / \mathrm{l}$.

During the transport cycle with a combined vehicle, $160.6 \mathrm{~km}$ were traveled between the route of the forest to industrial unit. According to Silva et al. (2007) the use of the road train was feasible up to a maximum distance of $226.0 \mathrm{~km}$. Therefore, the distance traveled was economically viable.

By varying the operating speed and the transport cycle time by $\pm 10 \%$ with the articulation, there were no significant changes in the final consumption of the transport cycle in terms of changes in distance traveled and load carried.

The response surface of the estimated consumption of the articulated vehicle was elaborated with the distance covered varying from 132.0 to $161.7 \mathrm{~km}$ and with a load carried from 31,000.00 to 38,200.0 kg. Of these, there was an estimated consumption of 95.0 to 120.0 1/cycle.

Going $148.5 \mathrm{~km}$ of total transport cycle with the use of articulated, loaded on average $34.200 .0 \mathrm{~kg}$, would be consumed 108.2 1. For the smaller transport distance $(132.0 \mathrm{~km})$, load of $27,500.0 \mathrm{~kg}$ (maximum quantity as to not exceed $48.500,0 \mathrm{~kg}$ of wood allowed by the legislation), there would be a consumption of 95,6 1 and an efficiency of $1,38 \mathrm{~km} / \mathrm{l}$.

The energy efficiency for the conjugated one $(1,2 \mathrm{~km} / \mathrm{l})$ and for the articulated one $(1,38 \mathrm{~km} / \mathrm{l})$ had been smaller than what was found for Klvac et al. (2013), equivalent the $1.71 \mathrm{~km} / \mathrm{l}$ in the Republic Czech. However, they were similar to the consumption found by Holzleitner and Kanzian (2011) of $1.3 \mathrm{~km} / \mathrm{l}$ resulting from transport in Austria.

\section{CONCLUSIONS}

- The variable that more influenced in the sensitivity of the fuel consumption of the vehicles in the distance was covered, followed for the liquid load carried and the operational speed. The largest expenditure occurred on empty and loaded journeys because they had traveled the longest distances.

- The sensitivity analysis and the response surface as a function of the variables selected allowed us to identify the combination of distance traveled and load carried by the lowest fuel consumption in each element of the road transport operating cycle with the conjugate and articulated.

- The combined vehicle is recommended for the longest distances, as well as the articulation should be destined to the smaller routes, aiming at lower fuel consumption and maximization of the amount of wood transported by forest road transportation cycle.

\section{REFERENCES}

ALVES, RT; FIEDLER, NC; SILVA, EN; LOPES, ES; CARMO, FCA Technical and cost analysis of the transportation of wood with different vehicle compositions. Tree Magazine. Vicesa, v. 37, n. 5, p. 897-904, 2013.

ANTONIADE, C .; SLINCU, C .; STAINS, C .; CIOBANU, C .; STE FAN, C. Maximum loading heights for heavy vehicles used in timber transportation. Agricultural Food Engineering. Transylvania, v. 5, n. 1, p. 7-12, 2012.

BRAZIL, Resolution No. 12 of February 6, 1998. Provides for the classification of road transport vehicles. Official Journal of the Federative Republic of Brazil, Brasília, DF. Pg.89, February 1998, Section 1.

FLORESTA, Curitiba, PR, v. 49, n. 2, p. 155-162, abr/jun 2019. 
BENETTI, BB; BRANDELERO, C.; GINDRI, EP; SILVA, GM; WERNER, V. Technical information for selection of mechanical horses for road transport. Technology. Santa Cruz do Sul, v. 22, n. 1, p. 85-89, 2018.

CARMO, FCA; FIEDLER, NC; LOPES, ES; PEREIRA, DP; MARIN, HB; SILVA, EN Analysis of the optimal density of forest roads in rural properties. Cerne. Lavras, v. 19, n. 3, p. 451-459, 2013.

Guidelines for Assembly of Bodyworks and General AXOR Equipment (2014) and Resolution Available in: <http://www.mercedes-benz.com.br/resources/files/documentos/caminhoes/axor/manual-deimplementacao/manual-de-implementacao-euro-3-axor-pt.pdf> Access in: 29/07/2014

ELLER, RAG; SOUSA JUNIOR, WC; CURI, MLC Cost of freight transport in Brazil: road versus rail. Journal of Transport Literature, v. 5, n. 1, p. 50-64, 2011.

EMMERT, F.; PEREIRA, RS; REZENDE, AV; ENCINAS, JMI Geoprocessing as a tool to support the management of pavements on forest roads. Forest Science. v. 20, n. 1, p. 81-94, 2010.

FIEDLER, NC Harvesting and transportation in steep areas. Reviews Opinions. However, 27, 2012. Available in: <http://florestal.revistaopinioes.com.br/revista/detalhes/23-colheita-e-transporte-em-areas-declivosas/> Accessed on: 15/03/2018

HOLZLEITNER, F .; KANZIAN, C. Analyzing time and fuel consumption in road transport of round wood with an onboard fleet manager. European Journal of Forest Research, v. 130, p. 293-301, 2011.

GUIMARAES, PP; ARCE, JE; FIEDLER, NC; ROBERT, RC Forest road transport. Encyclopedia Biosphere. Goiânia, v. 13, n. 24, p. 780-794, 2016 a.

GUIMARAES, PP; ARCE, JE; LOPES, ES; PELISSARI, AL; SALAMI, G .; CASTRO, VG Modeling of fuel consumption for forest transportation. Caatinga Magazine. v. 29, n. 2, p. 496-506, 2016 b.

GUIMARAES, PP; ROMANO, CA; CATAI, RE; PRADO, LN; PELISSARI, AL Profile of the forest road transport driver in the Municipality of Campo do Tenente-PR. Encyclopedia Biosphere. v. 9, n. 17, p. 3603-3617, 2013.

KLVAC, R .; KOLARIK, J .; VOLNÁ, M ; DRÁPELA, K. Fuel consumption in timber haulage. Croatian Journal of Forest Engineering. v. 34, n. 2, p.229-240, 2013.

MACHADO, CC; LOPES, ES; BIRRO, MHB; MACHADO, RR Forest road transport. Viçosa: Publisher of the Federal University of Viçosa; 2nd Edition, 217 p, 2009.

QUADROS, DS; MALINOVSKI, JR Economic analysis of forest service companies in two regions of the State of Santa Catarina. Forest. v. 42, n. 1, p. 35-48, 2012.

SEIXAS, F.; WIDMER, JA Selection and dimensioning of the road vehicle fleet for the main transport of wood using non-integer linear programming. Institute for Research and Forest Studies. Piracicaba, n. 46, p.107-118, 1993.

SILVA, ML; OLIVEIRA, RJ; VALVERDE, SR; MACHADO, CC; PIRES, VAV Analysis of the cost and economic radius of transporting wood from reforestation for different types of vehicles. Tree Magazine. Vicesa, v. 31, n. 6, p. 1073-1079, 2007.

VASCO, R. A, MORABITO, R. Optimization in the dynamic allocation of vehicles in road transport of complete loads between terminals. Management \& Production. v. 21, p. 271-284, 2014. 